\title{
PERSISTENCE AND PREDICTIVE ABILITY OF EARNINGS: EVIDENCE FROM FRANCE AND THE UK
}

\author{
Bilal KIMOUCHE
}

\author{
The Université of 20 Août 1955, Skikda, Algeria \\ Corresponding author's e-mail: b.kimouche@univ-skikda.dz
}

\begin{abstract}
The persistence and predictive ability are extensively requested as desirable attributes of earnings quality in the literature. The paper aims at investigating the persistence and predictive ability of earnings in French and UK companies. The study included a panel data of 1035 firm-year observations for 115 French listed companies from the CAC All-Tradable and 900 firm-year observations for 100 UK listed companies from the FTSE All-Share, during the period of 2011-2019. The research design was based on two equations starting from Sloan (1996) that were estimated using Fixed Effects Method. The study showed that earnings were persistent but they had no predictive ability regarding the future cash flows whether in French or UK companies and that earnings of UK companies were more persistent than those of the French companies. We argue that the persistence of earnings and the inability to predict future cash flows can be evidence of earnings management. The study contributes to the literature about earnings quality by studying earnings persistence and earnings predictive ability together in two different environments. The results require that users must take into consideration the illusory persistence of earnings, auditors must be cautious regarding the manipulation of earnings by managers, and accounting standard setters must review the reporting guidelines of cash flows to enhance their predictability by earnings.
\end{abstract}

Keywords: Cash flows from operations, Current earnings, Earnings persistence, French companies, Future cash flows, Future earnings, Predictive ability of earnings, UK companies.

JEL Classification: M40; M41.

\section{INTRODUCTION}

For many decades, earnings quality has been considered the pertinent measure of accounting quality since it has a crucial role in resource allocation in stock markets; it is difficult for all parties to ignore that fact (Lyimo, 2014, p. 17; Legenzova, 2016). As a result, managers seek meeting analysts' forecasts as a way to maximize the value of their companies for investors or to serve their interests, while analysts are concerned with the perfect measure of earnings quality to maximize the portfolio of investors (Kimouche, 2021). Likewise, the company's valuation is often relying on the expectation of future cash flows (Pivorienè, 2017), which requires a high predictive ability of current earnings. If the predictive ability of earnings is low, it is necessary to establish an association between future cash flows and future earnings, and then another association between future earnings and 
current earnings, the last association is known as earnings persistence (Kimouche, 2020).

According to IASB $(2018$, p. 31$)$, the relevance of financial reports that refers to the predictive and confirmatory value of information conveyed by these reports requires sustainable or core earnings. Consequently, persistence and predictive ability of earnings are the main attributes of earnings quality leading earnings to be a good indicator for future performance of the company (Bissessur, 2008, p. 40). Penman \& Zhang (2002) consider that the persistence and predictive ability of earnings are good proxies of earnings quality because earnings have high quality when they are sustainable and/or predictor. Earnings are extensively used for the purposes of contracting, debt assessment, and valuation, in order to make optimal capital allocation decisions (Canina and Potter, 2019, p. 40). Therefore, the persistence and predictive ability of earnings is desirable to reduce risk in assessing company value and contracting (Sun, 2010).

According to Sloan (1996), earnings persistence as an attribute of earnings quality attempts to employ current earnings to follow future earnings walk. Earnings persistence can be defined as the extent to which current earnings are a good predictor of future earnings, while earnings predictive ability can be defined as the extent to which current earnings are a good predictor of future cash flows from operations. Therefore, the two concepts require sustainability, less volatility, and permanence of earnings (Clubb \& Wu, 2014; Licerán-Gutiérrez \& CanoRodríguez, 2019). This situation needs some caution as it can be achieved through income smoothing practices and, thus, distorting earnings quality.

There are some links between persistence and predictive ability of earnings and other proxies of earnings quality like conservatism, earnings management, income smoothing, and value relevance. On the one hand, conservatism is expected to penalize the persistence and predictive ability of earnings because it is a source of special items. However, earnings management and income smoothing are expected to favour the persistence and predictive ability, which can provide virtual persistent and predictor earnings and, thus, mislead users of financial reports. On the other hand, persistence and predictive ability of earnings can enhance the value relevance of earnings by providing better inputs for valuation models.

The goal of this paper is to investigate the persistence and predictive ability of earnings in France and the UK in 7order to determine if there are differences between French and UK companies regarding these characteristics. We have chosen France and the UK because they represent two dominant accounting and economic models in the world, the Continental European versus the Anglo-American. We have used the auto-regression model of Sloan (1996) for panel data estimated through the Fixed Effects Model. The remainder of the paper is structured as follows: Section 1 reviews the literature, Section 2 presents the data and methodology, and Section 3 discusses the results.

\section{LITERATURE REVIEW}

The behaviour of earnings and other accounting variables and the explanation of that behaviour have been the preoccupation of researchers and professionals for 
many decades, especially with the emergence of stock markets. Many studies have been concerned with the prediction of the company's future performance for many purposes like valuation and contracting. The idea that current earnings are the starting point to predict future performance is not new; it was the subject of many studies since the early 1950s (Graham and Dodd, 1951; Ball and Brown, 1968; Watts and Leftwich, 1977; Lipe, 1986). Lev (1983) found that earnings autocorrelation was affected by the product type, competition, and operating leverage, while earnings variability was affected by product type and firm size.

Ball and Watts (1972) concluded that annual revenues followed a submartingale process, while Watts and Leftwich (1977) revealed that annual revenues followed a random walk process. During the three last decades, studies were more focused on the characteristics of earnings due to their importance as an aggregate of performance. In this regard, Givoly and Hayn (2000) documented changes in the behaviour of earnings, operating cash flows, and accounting accruals over the five decades from 1950 to 1998. Cupertino and Galimberti (2009) found that the persistence of earnings was not homogenous between the Brazilian companies during the period of 1995-2007 and that the accrual component of earnings did not have any effect on earnings persistence.

There are several streams of studies about the persistence and predictive ability of earnings. Exploring the quality of earnings in terms of persistence and predictive ability, Ebaid (2011) found that earnings of Egyptian listed companies during the period of 1999-2007 were persistent, and their persistence was attributed more to cash flows than accruals. He also revealed that the reliability of accruals affected positively their persistence. Kabir and Laswad (2011) examined four properties of the net and comprehensive income (persistence, variability, predictive ability, and value relevance) for the New Zealander listed companies during 2010. The results did not show any difference between net and comprehensive income regarding predictive ability and volatility. However, the results indicated the superiority of net income over comprehensive income in terms of persistence and value relevance.

For example, earnings persistence in Korean companies during the period of 1995-2006 was lower compared to the developed countries (An, 2017). Dimitropoulos and Koronios (2018) indicated that current cash flows had more predictive ability of future earnings than current earnings for 109 European top-tier clubs during the period of 2008-2016. Senan (2019) found that current cash flows from operations had more predictive ability compared to current earnings for the Saudi companies during the period of 2006-2015, and he also found that accruals increased the predictive ability of current earnings. Kimouche and Charchafa (2020) concluded that for Algerian companies' earnings were persistent but presented a weak predictive ability. Pirveli (2020) revealed that for the large Georgian companies, earnings and cash flows from operations were persistent at less than $25 \%$ and $40 \%$, respectively, and were able to predict less than $20 \%$ of the next period earnings and less than $35 \%$ of the next period operating cash flows, respectively. Kimouche (2021) indicated that earnings, operating cash flows, and accruals of Algerian companies were persistent, but their level of persistence was lower compared to developed countries. 
Another stream of studies was devoted to the interaction of persistence and predictive ability with other proxies of earnings quality. For example, Kazemi, Hemmati and Faridvand (2011) found a direct relationship between conservative accounting and other characteristics of earnings, including persistence, predictive ability, and value relevance. However, the relationship between conservative accounting and earnings timeliness was not statistically significant. Ben Mhamed and Jilani (2015) showed an inverse volatility-earnings predictability relation, indicating the ability of earnings volatility to predict earnings for the most profitable Canadian companies over the period of 2006-2011. Jelodari and Kordshouli (2016) suggested that earnings quality provided highly rigorous forecasts for operating cash flows.

Kordestani et al. (2016) proved that the timely loss recognition did not affect the persistence and the predictive ability of earnings in Iranian listed companies during the period of 2003-2010, which implied that accounting conservatism did not distort earnings quality. Carvalho, Camargo and Kalatzis (2017) suggested that earnings quality attributes, including earnings predictive ability, were good explicators of operational and market performance of Latin American companies over the period of 1989-2009. Kundu and Banerjee (2021) suggested that Indian listed companies that reported better earnings in terms of predictive ability generated higher stock returns. Kim (2021) provided evidence that more volatile and unpredictable earnings were associated with less accurate analyst forecasts in companies listed on Korean stock markets over the period of 1995-2006.

The third stream of studies was concerned with the accounting determinants of persistent and predictive ability. Dechow and Ge (2006) showed that low earnings persistence was mainly driven by special items during the period of 1988-2002. Atwood, Drake, and Myers (2010) found that when book-tax conformity was higher, earnings were less persistent and less predictive of future cash flows. Hardiningsih, Hadi and Ariani (2018) showed that book-tax difference and earning aggressiveness affected negatively earnings persistence; these effects were strengthened by corporate governance. Adiati, Rahmawati and Bandi (2018) suggested that deferred tax and accounting accruals affected negatively earnings persistence in the Indonesian listed companies during the period of 2007-2014. Doukakis (2010) suggested that guidelines measurement and reporting of IFRS did not improve both the persistence of earnings and its components. Martinez, Tolentino de Souza and Monte-Mor (2016) observed that earnings became less persistent after the IFRS adoption in the Brazilian context.

The last stream of studies dealt with the economic determinants of persistence and predictive ability. Pimentel and de Aguiar (2012) suggested that earnings persistence was negatively associated with inflation and interest rates in Brazilian listed companies. Rajizadeh and Rajizadeh (2013) examined factors affecting earnings persistence in the companies listed on the Tehran stock exchange; they revealed that operating cash flows, firm size, interest-bearing debts, and directors' independence directly impacted earnings persistence. Francis et al. (2014) found strong effects of cost of equity on accounting-based attributes of earnings quality, including persistence and predictive ability, over the period of 1975-2001. Canina and Potter (2019) found that barriers to entry and revenue diversification had 
positive impacts on the persistence and predictive ability of earnings in the USA over the period of 1997-2015.

The previous studies have explored different aspects of the persistence and predictive ability in terms of measurement, importance, determinant factors, and relationship with other proxies of earnings quality. These aspects have been investigated in different environments, especially in developed and emerging countries and to a lesser degree in developing countries. This study contributes to the literature about earnings quality by studying earnings persistence and the predictive ability together in two different environments that represent the poles of the two dominant accounting and economic models in the world (Continental European and Anglo-American, respectively).

\section{DATA AND METHODOLOGY}

\subsection{Sample and Data}

This study includes 115 French listed companies from the CAC All-Tradable and 100 UK listed companies from the FTSE All-Share, during the period of 20112019, which represents 1035 firm-year observations from France and 900 firm-year observations from the UK. The variables have been measured using the amounts obtained from the financial statements and weighted using the total assets at the end of the period. We used the panel data of each country separately and without excluding any observations.

\subsection{Model Specification}

The model of study includes two equations under the form of linear regressions starting from Sloan (1996). The two equations were estimated using the data of French and UK companies each one separately. Equation (1) is an auto-regression model of earnings that measures earnings persistence by relating the earnings of the next period with the earnings of the current period.

$$
N I_{i t+1}=\alpha_{0}+\alpha_{1} N I_{i t}+\xi_{\text {it. }}
$$

Equation (2) is a linear regression that measures the predictive ability of earnings by relating the cash flows of the next period with the earnings of the current period.

$$
O C F_{i t}+1=\beta_{0}+\beta_{1} N I_{i t}+\zeta_{i t}
$$

where:

$N I_{i t}$ is the profit or loss for the period;

$O C F_{i t}$ is the net cash flows from operations for the period;

$\alpha_{0}, \beta_{0}$ are intercepts;

$\alpha_{1}, \beta_{1}$ are regression coefficients that measure the persistence and predictive ability of earnings;

$\xi_{\text {it }}$ and $\zeta i_{t}$ are the error terms. 


\subsection{Hypotheses of the Study}

This study attempts to test the following hypotheses:

- Hypothesis 1: earnings of French companies are persistent and have predictive ability.

- Hypothesis 2: earnings of UK companies are persistent and have predictive ability.

\section{RESULTS AND DISCUSSION}

\subsection{Descriptive Statistics}

Table 1 presents the descriptive statistics of data collected from the French and UK companies. The total of observations reached 1035 firm-years for French companies and 900 firm-years for UK companies. However, there are 115 and 100 firm-years, respectively, that are missed due to the time lag in the current earnings $\left(N I_{i t}\right)$. According to the results, there is a homogeneity between the descriptive statistics of the next period earnings $\left(N I_{i t+1}\right)$ and current earnings $\left(N I_{i t}\right)$ whether in the French or UK companies, considering that the first variable was abstracted from the second as the lagged of one-year period. Table 1 shows that French companies earn $7.76 \%$ of total assets on average and they have the best performance compared to UK companies that earn $6.46 \%$ of total assets on average. French companies generate $2.9 \%$ of total assets on average as net cash flows from operations $\left(O C F_{i t+1}\right)$ more than UK companies that generate only $0.16 \%$ of total assets on average. Concerning the dispersion, data of French companies are more dispersal than UK companies, and data of the next period cash flows from operations $\left(O C F_{i t+1}\right)$ are more dispersal than current $\left(N I_{i t}\right)$ and future earnings $\left(N I_{i t+1}\right)$ in the two cases.

Table 1. Descriptive Statistics of Variables

\begin{tabular}{|l|l|l|l|l|l|l|}
\hline & \multicolumn{3}{|l|}{ French companies } & \multicolumn{3}{l|}{ UK companies } \\
\hline & $\boldsymbol{N I}_{\boldsymbol{i t}+\mathbf{1}}$ & $\boldsymbol{O C F}_{\boldsymbol{i t + 1}}$ & $\boldsymbol{N I}_{\boldsymbol{i t}}$ & $\boldsymbol{N I}_{\boldsymbol{i t}+\mathbf{1}}$ & $\boldsymbol{O C F}_{\boldsymbol{i t + 1}}$ & $\boldsymbol{N I}_{\boldsymbol{i t}}$ \\
\hline Mean & 0.0776 & 0.0290 & 0.0795 & 0.0660 & 0.0016 & 0.0646 \\
\hline Median & 0.0506 & 0.0060 & 0.0508 & 0.0425 & 0.0025 & 0.0419 \\
\hline Maximum & 0.4612 & 1.6654 & 0.4612 & 0.5566 & 0.8361 & 0.5677 \\
\hline Minimum & -0.7140 & -1.9961 & -0.7140 & -0.5265 & -1.5218 & -0.5265 \\
\hline Std. Dev. & 0.1362 & 1.6994 & 0.1401 & 0.0932 & 0.1763 & 0.0923 \\
\hline Observations & 920 & 920 & 1035 & 800 & 800 & 900 \\
\hline Missing & - & - & 115 & - & - & 100 \\
\hline \multicolumn{7}{|c|}{ Source: The author's calculation } \\
\hline
\end{tabular}

\subsection{Correlation}

Table 2 shows the results of the correlation between the three variables of the model of study. It appears that the correlation between cash flows from operations 
$\left(O C F_{i t+1}\right)$ and current earnings $\left(N I_{i t}\right)$ is not statistically significant both in French and UK companies, where the significance levels reached 0.777 and 0.655 , respectively, and they are more than $5 \%$. This means that no predictive ability is expected from the current earnings. On the contrary, the correlation between the next period earnings $\left(N I_{i t+1}\right)$ and current earnings $\left(N I_{i t}\right)$ is statistically significant at $1 \%$ level of significance both in French and UK companies. Therefore, current earnings are expected to predict future earnings and, hence, are expected to be persistent.

Table 2. The Results of the Correlation between Variables

\begin{tabular}{|l|l|l|l|l|}
\hline & & & $N_{i t+1}$ & $\boldsymbol{O C F}_{i t+1}$ \\
\hline \multirow{4}{*}{$N I_{i t}$} & \multirow{3}{*}{ French companies } & Pearson correlation & 0.479 & -0.009 \\
\cline { 3 - 5 } & \multirow{2}{*}{ UK companies } & Sig. (2-tailed) & 0.000 & 0.777 \\
\cline { 3 - 5 } & Pearson correlation & 0.530 & -0.016 \\
\cline { 3 - 5 } & Sig. (2-tailed) & 0.000 & 0.655 \\
\hline
\end{tabular}

Source: The author's calculation

\subsection{Persistence and Predictive Ability of Earnings in French Companies}

Table 3 summarises the results of estimating Model (1) and Model (2) using the data of French companies. As shown in Table 3, the results of regressions are consistent with the results of the correlation indicating that the current earnings do not impact the cash flows of the next period, so earnings have no predictive ability with regard to cash flows because Model (2) is not statistically significant whether at $1 \%$ or at $5 \%$. On the contrary, Model (1) is statistically significant at $1 \%$ level, so the current earnings impact and predict the next period earnings and, thus, earnings are persistent.

Table 3. The Model Estimation Results in French Companies

\begin{tabular}{|c|c|c|c|c|c|c|}
\hline \multirow[b]{2}{*}{ Variable } & \multicolumn{3}{|c|}{$\begin{array}{c}\text { Persistence } \\
N I_{i t+1}=\alpha_{0}+\alpha_{1} N I_{i t}+\xi_{i t}\end{array}$} & \multicolumn{3}{|c|}{$\begin{array}{c}\text { Predictive ability } \\
O C F_{i t+1}=\beta_{0}+\beta_{1} N I_{i t}+\zeta_{i t}\end{array}$} \\
\hline & Coefficient & $t$-Stat. & Prob. & Coefficient & $t$-Stat. & Prob. \\
\hline$N I_{i t}$ & 0.1138 & 3.1326 & 0.0018 & -0.9187 & -0.3462 & 0.7292 \\
\hline Intercept & 0.2995 & 14.308 & 0.0000 & -5.8348 & -0.5130 & 0.6080 \\
\hline Estimation & \multicolumn{3}{|c|}{ Fixed Effects Method } & \multicolumn{3}{|c|}{ Fixed Effects Method } \\
\hline$R^{2}$ & \multicolumn{3}{|c|}{0.4375} & \multicolumn{3}{|c|}{0.0020} \\
\hline$F$-Stat. & \multicolumn{3}{|c|}{5.0503} & \multicolumn{3}{|c|}{0.9850} \\
\hline Prob.(F-stat.) & \multicolumn{3}{|c|}{0.0000} & \multicolumn{3}{|c|}{0.5297} \\
\hline Observations & \multicolumn{3}{|c|}{920} & \multicolumn{3}{|c|}{920} \\
\hline
\end{tabular}

The regression coefficient of the current earnings is statistically significant at $1 \%$ and reached 0.1138 indicating a positive impact of the current earnings on the 
next period earnings. The determination coefficient suggests that the current earnings can predict $43.75 \%$ of the next period earnings. These results confirm partially Hypothesis 1; they suggest that earnings of French companies are persistent but they have no predictive ability regarding the future cash flows.

\subsection{Persistence and Predictive Ability of Earnings in UK Companies}

Table 4 summarises the estimation results of Model (1) and Model (2) using the data of UK companies, which present homogenous properties with the previous results obtained from the data of French companies. Like the results of the correlation, it appears that Model (2) is not statistically significant, so the current earnings do not impact the next period cash flows and do not present any predictive ability. Contrarily, Model (1) is significant at $1 \%$ level, and therefore the current earnings can predict the next period earnings, which mean that earnings of UK companies are persistent. The regression coefficient relating to the current earnings is statistically significant at $1 \%$ level and indicates a positive impact of the current earnings on the next period earnings. The determination coefficient revealed that the current earnings predict $52.48 \%$ of the next period earnings. Like the case of French companies, these results confirm partially Hypothesis 2 indicating that earnings of UK companies are persistent, while they have no predictive ability regarding the future cash flows.

Table 4. The Model Estimation Results in UK companies

\begin{tabular}{|c|c|c|c|c|c|c|}
\hline \multirow[b]{2}{*}{ Variable } & \multicolumn{3}{|c|}{$\begin{array}{c}\text { Persistence } \\
N I_{i t+1}=\alpha_{0}+\alpha_{1} N I_{i t}+\xi_{i t}\end{array}$} & \multicolumn{3}{|c|}{$\begin{array}{c}\text { Predictive ability } \\
O C F_{i t+1}=\beta_{0}+\beta_{1} N I_{i t}+\zeta_{i t}\end{array}$} \\
\hline & Coefficient & $t$-Stat. & Prob. & Coefficient & $t$-Stat. & Prob. \\
\hline$N I_{i t}$ & 0.1018 & 2.7139 & 0.0068 & -0.0304 & -0.3055 & 0.7600 \\
\hline Intercept & 0.3044 & 17.422 & 0.0000 & 0.0105 & 0.2266 & 0.8208 \\
\hline Estimation & \multicolumn{3}{|c|}{ Fixed Effects Method } & \multicolumn{3}{|c|}{ Fixed Effects Method } \\
\hline$R^{2}$ & \multicolumn{3}{|c|}{0.5248} & \multicolumn{3}{|c|}{0.0267} \\
\hline$F$-Stat. & \multicolumn{3}{|c|}{7.1447} & \multicolumn{3}{|c|}{0.8053} \\
\hline Prob.(F-stat.) & \multicolumn{3}{|c|}{0.0000} & \multicolumn{3}{|c|}{0.9188} \\
\hline Observations & \multicolumn{3}{|c|}{800} & \multicolumn{3}{|c|}{800} \\
\hline
\end{tabular}

\section{CONCLUSION}

Earnings persistence and earnings predictive ability are desirable attributes of earnings quality; they are extensively requested for the purposes of contracting, valuation, and information asymmetry reduction, especially in stock markets. The study included a panel data of 1035 firm-year observations for 115 French listed companies from the CAC All-Tradable and 900 firm-year observations for $100 \mathrm{UK}$ listed companies from the FTSE All-Share, during the period of 2011-2019. The 
research design was based on two equations starting from Sloan (1996) that were estimated using Fixed Effects Method for each country separately.

The study contributes to the literature about earnings quality by studying earnings persistence and earnings predictive ability together in two different environments. The study showed that earnings were persistent but they had no predictive ability regarding the future cash flows whether in French or UK companies and that earnings of UK companies were more persistent than those of French companies. In fact, the persistence of earnings and the inability to predict future cash flows can be evidence of earnings management through income smoothing or other practices. These results can be a sign that the quality of earnings in the UK is high compared to France or that UK companies are better practitioners of earnings management. Our results require auditors to be more cautious regarding the manipulation of earnings by managers; likewise users must take into consideration the illusory persistence of earnings. Accounting standard setters must review the reporting guidelines of cash flows to enhance their predictability by earnings. Finally, future studies are invited to study the relationship between earnings persistence and earnings manipulation.

\section{REFERENCES}

Adiati, A. K., Rahmawati, R., \& Bandi, B. (2018). The Impact of Deferred Tax and Accruals on the Earnings Persistence of Companies in the non-Financial Sectors Listed on the Indonesia Stock Exchange. Journal of Accounting, Finance and Auditing Studies, 4(3), 1-18.

An, Y. (2017). Measuring Earnings Quality over Time. International Journal of Economics and Financial Issues, 7(3), 82-87.

Atwood, T. J., Drake, M. S., \& Myers, L. A. (2010). Book-Tax Conformity, Earnings Persistence and the Association between Earnings and Future Cash Flows. Journal of Accounting and Economics, 50(1), 111-125. https://doi.org/10.1016/j.jacceco.2009.11.001

Ball, R., \& Brown, P. (1968). An Empirical Evaluation of Accounting Income Numbers. Journal of Accounting Research, 6(2), 159-178. https://doi.org/10.2307/2490232

Ball, R., \& Watts, R. L. (1972). Some Time Series Properties of Accounting Income. Journal of Finance, 27(3), 663-681. https://doi.org/10.1111/j.1540-6261.1972.tb00991.x

Ben Mhamed, Y., \& Jilani, F. (2015). Earnings Volatility and Earnings Predictability. Journal of Business Studies Quarterly, 6(3), 36-53.

Bissessur, S. W. (2008). Earnings Quality and Earnings Management: The Role of Accounting Accruals (PhD thesis). Amsterdam, Rotterdam: Thela Thesis.

Canina, L., \& Potter, G. (2019). Determinants of Earnings Persistence and Predictability for Lodging Properties. Cornell Hospitality Quarterly, 60(1), 40-51. https://doi.org/10.1177\%2F1938965518791729

Carvalho, F. L., Camargo, M. B., \& Kalatzis, A. (2017). Earnings Quality Attributes and Investment Opportunities for Latin American Firms. Advances in Scientific and Applied Accounting, 10(1), 110-131. http://doi.org/10.14392/asaa.2017100107

Clubb, C., \& Wu, G. (2014). Earnings Volatility and Earnings Prediction: Analysis and UK Evidence. Journal of Business Finance and Accounting, 4(1-2), 53-72. https://doi.org/10.1111/jbfa.12055

Cupertino, C. M., \& Galimberti, G. K. (2009). Explaining Earnings Persistence: A Threshold Autoregressive Panel Unit Root Approach. MPRA Working Paper 14237. Germany: Munich Personal RePEc Archive.

Dechow, P. M., \& Ge, W. (2006). The Persistence of Earnings and Cash Flows and the Role of Special Items: Implications for the Accrual Anomaly. Review of Accounting Studies, 11(2-3), 253-296. http://doi.org/10.1007/s11142-006-9004-1 
Dimitropoulos, P. E., \& Koronios, K. (2018). Earnings Persistence of European Football Clubs under UEFA's FFP. International Journal of Financial Studies, 6(43), 1-15. http://doi.org/10.3390/ijfs6020043

Doukakis, L. C. (2010). The Persistence of Earnings and Earnings Components after the Adoption of IFRS. Managerial Finance, 36(11), 969-980. https://doi.org/10.1108/03074351011081286

Ebaid, I. E. (2011). Persistence of earnings and earnings components: Evidence from the emerging capital market of Egypt. International Journal of Disclosure and Governance, 8(2), 174-193. https://doi.org/10.1057/jdg.2010.29

Francis, J., LaFond, R., Olsson, P. M. \& Schipper, K. (2004). Costs of Equity and Earnings Attributes. The Accounting Review, 79(4), 967-1010. http://www.jstor.org/stable/4093083

Givoly, D., \& Hayn, C. (2000). The Changing Time-Series Properties of Earnings, Cash Flows and Accruals: Has Financial Reporting become more Conservative? Journal of Accounting and Economics, 29(3), 287-320. https://doi.org/10.1016/S0165-4101(00)00024-0

Graham, B., \& Dodd, D. L. (1951). Security Analysis. New York: McGraw-Hill.

Hardiningsih, P., Hadi, T. P., \& Ariani, N. (2018). Determinant Earnings Persistence with Corporate Governance as Moderating Factors. Proceedings of the International Conference on Banking, Accounting, Management, and Economics (ICOBAME 2018). https://doi.org/10.2991/icobame$\underline{18.2019 .17}$

IASB (2018). The Conceptual Framework for Financial Reporting. London: IFRS Foundation.

Jelodari, A., \& Kordshouli, F. A. (2016). A survey of the role of earnings quality in accurately forecasting of operational and cash circulation of companies listed on Tehran stock exchange. International Journal of Academic Research in Accounting, Finance and Management Sciences, 6(4), 82-89.

Kabir, M. H., \& Laswad, F., (2011). Properties of Net Income and Total Comprehensive Income: New Zealand Evidence. Accounting Research Journal, 24(3), 268-289. https://doi.org/10.1108/10309611111187000

Kazemi, H., Hemmati, H., \& Faridvand, R. (2011). Investigating the Relationship Between Conservatism Accounting and Earnings Attributes. World Applied Sciences Journal, 12(9), $1385-1396$.

Kim, J. (2021). Earnings Attributes that Contribute to Analyst Forecasting Errors: Empirical Evidence from Korea. Journal of Asian Finance, Economics and Business, 8(8), 647-658. https://doi.org/10.13106/jafeb.2021.vol8.no8.0647

Kimouche, B., \& Charchafa, I. (2020). Characteristics of Accounting Earnings in the Algerian Companies. Proceedings of the $2^{\text {nd }}$ International European Conference on Interdisciplinary Scientific Researches, July 4-5, Ankara, Turkey: FARABI Publications, 407-416.

Kimouche, B. (2020). The Persistence of Accounting Accruals Components: An Empirical Study of Some Algerian Companies. Journal of Economic Sciences Institute, 23(2), 4142-4123. https://www.asjp.cerist.dz/en/article/140928

Kimouche, B. (2021). The Persistence of Earnings and Earnings Components: Evidence from Algerian Companies (2006-2017). Les Cahiers du Cread, 37(4).

Kordestani, G., Taqiporian, M., Biglari, V., \& Minaei, V. (2016). Persistence of Earnings and Prediction of Future Cash Flows: The Role of Timely Recognition of Bad News. Business: Theory and Practice, 17(4), 353-360. https://doi.org/10.3846/btp.17.11124

Kundu, K., \& Banerjee, A. (2021). Predictability of Earnings and its Impact on Stock Returns: Evidence from India. Cogent Economics \& Finance, 9(1), 1898112. https://doi.org/10.1080/23322039.2021.1898112

Legenzova, R. (2016). A Concept of Accounting Quality from Accounting Harmonisation Perspective. Economics and Business, 28(1) 33-37. https://doi.org/10.1515/eb-2016-0005

Lev, B. (1983). Some Economic Determinants of Time-Series Properties of Earnings. Journal of Accounting and Economics, 5, 31-48. https://doi.org/10.1016/0165-4101(83)90004-6

Licerán-Gutiérrez, A., \& Cano-Rodríguez, M. (2019). A Review on the Multidimensional Analysis of Earnings Quality. Revista de Contabilidad Spanish Accounting Review, 22(1), 41-60. https://doi.org/10.6018/rc-sar.22.1.354301

Lipe, R. C. (1986). The Information Contained in the Components of Earnings. Journal of Accounting Research, 24, 37-64. https://doi.org/10.2307/2490728 
Lyimo, G. D. (2014). Assessing the Measures of Quality of Earnings: Evidence from India. European Journal of Accounting Auditing and Finance Research, 2(6), 17-28.

Martinez, A. L., Tolentino de Souza, T. B., \& Monte-Mor, D. S. (2016). Book-Tax Differences, Earnings Persistence and Tax Planning before and after the Adoption of IFRS in Brazil. Advances in Scientific and Applied Accounting, 9(2), 162-180. http://doi.org/10.14392/asaa.2016090203

Penman, S. H., \& Zhang, X. J. (2002). Modeling Sustainable Earnings and P/E Ratios with Financial Statement Analysis. Forthcoming. https://doi.org/10.2139/ssrn.318967

Pimentel, R. C., \& De Aguiar, A. B. (2012). Economic Variables and Earnings Persistence in Brazil. The $36^{\text {th }}$ Encontro da ANPAD.

Pirveli, E. (2020). Earnings Persistence and Predictability within the Emerging Economy of Georgia. Journal of Financial Reporting and Accounting, 18(3), 563-589. http://doi.org/10.1108/JFRA03-2019-0043

Pivorienè, A. (2017). Real Options and Discounted Cash Flow Analysis to Assess Strategic Investment Projects. Economics and Business, 30(1), 91-101. https://doi.org/10.1515/eb-2017$\underline{0008}$

Rajizadeh, S., \& Rajizadeh, S. (2013). Examining the Factors Affecting Earnings Persistency among the Listed Firms in Tehran Stock Exchange. European Online Journal of Natural and Social Sciences, 2(3s), 2073-2079.

Senan, N. A. M. (2019). Ability of Earnings and Cash Flows in Forecasting Future Cash Flows: a Study in the Context of Saudi Arabia. Academy of Accounting and Financial Studies Journal, 23(1), 1-13.

Sloan, R. G. (1996). Do Stock Prices Fully Reflect Information in Accruals and Cash Flows about Future Earnings? The Accounting Review, 71(3), 289-315. http://www.jstor.org/stable/248290

Sun, Q. (2010). A Review of Literature on Earnings Persistence and its Implications. Journal of Xiamen University (Arts \& Social Sciences), Year 2010(1), 30-37.

Watts, R. L., \& Leftwich, R. W. (1977). The Time Series of Annual Accounting Earnings. Journal of Accounting Research, 15(2), 253-271. https://doi.org/10.2307/2490352

\section{AUTHOR'S SHORT BIOGRAPHY}

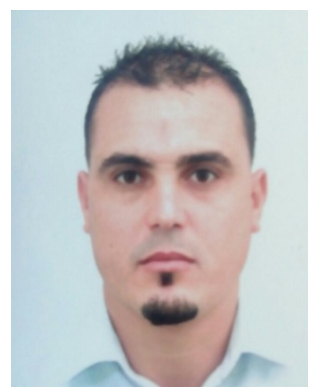

Bilal Kimouche obtained a $\mathrm{PhD}$ degree in Economics (2016) from the University of Setif 1, and later a Post-PhD degree from the University of Biskra (2018). He started as an Assistant at Université 20 Août 1955-Skikda (Algeria) in 2012. He has been a Lecturer of Accounting, Auditing, and Finance at the Department of Finance and Accounting in the same university since 2016. He was the Head of the Common Core Department at the Faculty of Economics, Commerce Sciences and Management Sciences in the same university from 2013 to 2019 . He has been the Dean of the Faculty of Economics, Commerce Sciences and Management Sciences in the same university since 2019 . His main fields of interest are financial accounting, managerial accounting, auditing, taxes, and corporate finance. He is the author of many books and articles in accounting and auditing.

E-mail: mailto:b.kimouche@univ-skikda.dz

ORCID iD: http://orcid.org/0000-0003-2609-7149 